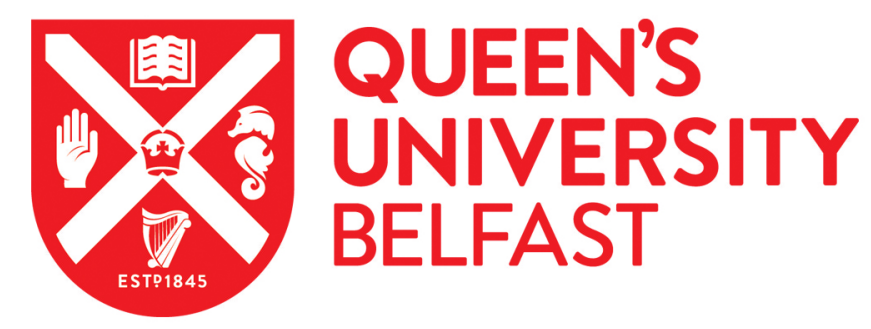

\title{
The post-political nature of marine spatial planning and modalities for its re-politicisation
}

Clarke, J., \& Flannery, W. (2019). The post-political nature of marine spatial planning and modalities for its repoliticisation. Journal of Environmental Policy and Planning, 22(2), 170.

https://doi.org/10.1080/1523908X.2019.1680276

Published in:

Journal of Environmental Policy and Planning

Document Version:

Peer reviewed version

Queen's University Belfast - Research Portal:

Link to publication record in Queen's University Belfast Research Portal

Publisher rights

Copyright 2019 Taylor and Francis. This work is made available online in accordance with the publisher's policies. Please refer to any applicable terms of use of the publisher.

\section{General rights}

Copyright for the publications made accessible via the Queen's University Belfast Research Portal is retained by the author(s) and / or other copyright owners and it is a condition of accessing these publications that users recognise and abide by the legal requirements associated with these rights.

Take down policy

The Research Portal is Queen's institutional repository that provides access to Queen's research output. Every effort has been made to ensure that content in the Research Portal does not infringe any person's rights, or applicable UK laws. If you discover content in the Research Portal that you believe breaches copyright or violates any law, please contact openaccess@qub.ac.uk. 
The post-political nature of marine spatial planning and modalities for its repoliticisation

Jane Clarke* and Wesley Flannery

School of Natural and Built Environment, Queen's University Belfast

jclarke323@qub.ac.uk; w.flannery@qub.ac.uk

* Corresponding author

This is a pre-print version of a paper published in the Journal of Environmental Policy and Planning and should be cited as:

Clarke, J., and Flannery, W. (2019) The post-political nature of marine spatial planning and modalities for its re-politicisation. Journal of Environmental Policy and Planning, DOI $\underline{10.1080 / 1523908 X .2019 .1680276}$

Link to published version:

https://www.tandfonline.com/doi/full/10.1080/1523908X.2019.1680276 


\begin{abstract}
Marine spatial planning (MSP) has become the most adopted approach for sustainable marine governance. While MSP has transformative capacity, evaluations of its implementation illustrate large gaps between how it is conceptualised and how it is practiced. We argue that these gaps arise from MSP being implemented through post-political processes. Although MSP has been explored through post-political lenses, these evaluations are incomplete and do not provide sufficient detail about the complex nature of the post-political condition. Drawing on seminal literature, we conceptualise the post-political as consisting of highly interconnected modalities of depoliticisation, including: neoliberalism; choreographed participation; path dependency; technocratic-managerialism; and the illusion of progressive change. Using these modalities as an analytical framework, we evaluate English MSP and find that it focuses on entrenching neoliberal logic through: tokenistic participation; wholescale adoption of path-dependent solutions; obstructionist deployment of inactive technological solutions; and promising progressive change. We do not, however, view the post-political condition as unresolvable and we develop a suite of suggestions for the repoliticisation of MSP which, collectively, could form the basis for more radical forms of MSP.
\end{abstract}

Keywords: marine spatial planning; post-political planning; marine governance; neoliberalism; participation

\title{
1. Introduction
}

Increasing demand for marine space, particularly from spatially-fixed industries such as wind farms, facilitates the view that Marine Spatial Planning (MSP) is "an idea whose time has come" (Ehler, 2018, p. 6). This claim is reflected in MSP's rapid adoption worldwide. MSP 
is framed as an integrated, forward-looking, and participatory approach to marine management. It is promoted as a rational means of achieving various objectives including Blue Growth, addressing democratic deficits, reducing stakeholder conflict, reducing cumulative negative impacts, regenerating coastal communities, and environmental conservation. MSP's broad appeal is based on its potential to transform marine governance. Marine governance is a multi-actor process wherein various agencies, governmental bodies, sectoral interests, and civil society organisations have shared competencies for policymaking and managing activities and their consequences (van Tatenhove, 2013). Historically, marine governance was highly fragmented, with management regimes focusing on individual sectors. MSP seeks to transform marine governance by: a) using space as a governance mechanism to address sectoral and fragmented management; and b) closing the democratic deficit through participatory planning (Flannery, Clarke, \& McAteer, 2019). There is, however, a body of evidence illustrating that MSP is failing to reform marine governance (Jones, Lierberknecht, \& Qiu, 2016; Smith \& Jentoft 2017; Tafon, Howarth, \& Griggs, 2018). In Scotland, for example, MSP initiatives have not mediated conflicting interests and failed to capture the potential of participative processes (Smith, 2018). Although these evaluations provide useful critiques of MSP practices, there is a dearth of studies that conceptualise why MSP has not achieved its promise, or that provide alternate avenues for realising its transformative potential.

We address these gaps by arguing that MSP's potential has been diminished as it is implemented through post-political processes. Post-political processes minimise engagement and meaningful debate, resist transforming the status quo, and contestation is eliminated and replaced by elite and technocratic-managerial governance. Researchers have begun to examine MSP through the post-political lens (Tafon, 2017; Flannery et al., 2016; 2018) but 
they focus on only one or two components of the post-political condition and do not provide holistic assessments of the overall governance regime. For example, Tafon (2017) and Flannery, Healy, \& Luna (2018) focus on the implications of neoliberal agendas and inadequate participation in MSP initiatives. Aligning with concerns about imprecise assessments of post-political planning (Metzger, 2017), we argue that it is comprised of several interrelated modalities of depoliticisation, described in the literature as symptoms of the post-political condition, that are impossible to disaggregate.

A review of the literature demonstrated that there were five common symptoms of the postpolitical condition: 1) neoliberal governance; 2) choreographed participation; 3) path dependency; 4) technocratic-managerialism; and 5) the illusion of progressive change. These symptoms, elaborated below, form the basis of our analytical framework. Adopting England's initial marine plan as a case study, this paper is the first assessment of the interrelated symptoms of post-political MSP. By assessing MSP through a holistic postpolitical lens, we can address the overall condition, rather than incrementally battling individual modalities of depoliticisation.

The next section provides an overview of MSP and the post-political condition. This is followed by an account of our study site and methodology. Key findings are then presented, leading to a discussion about the interrelated nature of the modalities of depoliticisation. The paper concludes with a suite of suggestions as to how the interrelated nature of these modalities can be resisted and new, more radical forms of MSP implemented. These alternative strategies should be considered collectively as the beginning of a framework for a more radical MSP. We do not propose this as a panacea, and it should be viewed as a first attempt to re-politicise MSP by recapturing its original transformative potential. 


\section{MSP and the post-political condition}

MSP is advanced as a sustainable governance approach that addresses spatial and temporal distributions of marine activities. MSP is framed as radically different from the sectoral management approach that preceded it. Whereas previous governance regimes were fragmented, sectoral and top-down, MSP is conceived as holistic, participatory and capable of addressing a range of concurrent issues, for example: implementing integrated ecosystembased management; reducing negative cumulative impacts; enabling transboundary governance; facilitating the expansion of maritime economies; and fostering participation and reducing stakeholder conflict.

Assessments of MSP in practice illustrate that there is a gap between how MSP is conceptualised and how it is implemented. In practice, MSP appears to repackage the status quo in empty participatory rhetoric (Ritchie \& Ellis, 2010; Flannery et al., 2016; Smith \& Jentoft, 2017), the development of weak objectives (Flannery \& Ó Cinnéide, 2012a; Sander, 2018) and the logic of technocratic governance (Smith \& Jentoft, 2018). These evaluations question MSP's capacity to address long-standing governance issues and the equitability of these processes (Flannery \& Ó Cinnéide, 2012b; Tafon et al., 2018). These assessments illustrate MSP's failure to transform marine governance (Kelly, Ellis, \& Flannery 2018), and how it may do little more than provide a semblance of democratic legitimacy to neoliberal exploitation (Flannery et al., 2018).

Many of MSP's failings have been attributed to it being implemented through post-political governance (Tafon, 2017; Flannery et al., 2016; 2018). Post-political governance is highly deceptive as it facilitates the elimination of counter-hegemonic opinions and actions through 
participatory and technocratic processes (Swyngedouw, 2009). Post-political describes situations in which the political is colonised by politics (Mouffe, 2005). In other words, the post-political describes processes in which spaces of contest or struggle (the political), are overrun by unchallenged frameworks of free-market economics, technocratic management, and consensual procedures (politics) (Wilson \& Swyngedouw, 2014). Contradictions to the neoliberal hegemony are "reduced to policy problems to be managed by experts and legitimated through participatory processes in which the scope of possible outcomes is narrowly defined in advance" (Wilson \& Swyngedouw, 2014, p. 6).

Post-political governance disempowers stakeholders by replacing debate and dissensus with "consensus, agreement, accountancy metrics and technocratic environmental management" (Swyngedouw, 2009, p. 604). The public is viewed as a disruptive collective and is replaced by 'enlightened' technocrats (Wilson \& Swyngedouw, 2014). Despite evidence that the established economic order Western, consumer-based societies is deeply unsustainable, the post-political conditions seek to minimise the threat of substantive structural change (Blühdorn, 2014). The post-political condition eliminates debate and dissensus by deploying depoliticising governance modalities, including: neoliberalism; choreographed participation; path dependency; technocratic-managerialism; and the illusion of progressive change.

\section{Neoliberalism}

Neoliberalism acts as a modality of depoliticisation in two ways. First, neoliberalism frames policy issues so that the continuation of the neoliberal hegemony is viewed as the solution to all crises (Wilson \& Swyngedouw, 2014). Proponents of neoliberalism seek to naturalise it as the only possible approach by structuring policy crises and responses so that they continue to produce neoliberal states, spaces and subjects. Neoliberalism depoliticises environmental planning by obscuring the possibility of alternative discourses or actions, and by hiding its 
insidious agenda within policy solutions (Haughton, Allmendinger, \& Oosterlynck, 2013). Under the guise of regeneration, neoliberalism de-politicises public spaces to deliver megaprojects for private gain.

Second, neoliberalism extinguishes the political aspects of democracy, which neoliberals see as being infused with unnecessary deliberation and as a delay to the significant work of production and gratification (Harvey, 2007). Neoliberalism does this by ensuring buy-in from selected partners, whilst also delegitimising the actions of those seeking to instigate counterhegemonic practices. Those not seeking the transformation of the hegemony, who, instead, make their demands negotiable within already defined policy frameworks, are deemed legitimate participants in planning processes (Oosterlynck \& Swyngedouw, 2010). Neoliberalism depoliticises planning by disarticulating local issues, as these are precluded from being legitimate critiques of governance practices (Oosterlynck \& Swyngedouw, 2010). Neoliberalism forces communities to work with selected actors to secure sparse resources (e.g. local jobs), at the expense of political mobilisation. Rather than appear undemocratic, post-political governance hides this issue within choreographed participation.

\section{Choreographed participation}

Choreographed participation is deployed to legitimise undemocratic processes (Allmendinger \& Haughton, 2012). Choreographed participation does this by engineering opportunities for engagement and dissent (Metzger, 2017). The post-political condition has emerged from the uncritical adoption of consensual decision making (Swyngedouw, 2009). While consensus is not an inherently undesirable outcome, it can be deployed as a mechanism of depoliticisation (Raco, 2014). The obsessive focus on consensus is used, perversely, to narrow participation to those who are amenable to the established hegemony and to castigate those who challenge 
it. Conflict and debate are depicted as disruptive processes with detrimental consequences for consensus; debate is unnecessary and disruptive voices may be removed (Mouffe, 2005). By eviscerating debate and dissensus from democratic processes, choreographed participation preserves neoliberal tendencies and steers agreement towards lowest common denominator objectives (Swyngedouw, 2009). Participants in these processes are paradoxically told they are being empowered, whilst their ability to influence outcomes are undermined in a drive to achieve 'consensus'.

Choreographed participation also removes the link between participation and validation by shifting the focus from input to output forms of legitimisation (Raco, 2014). Participation in post-political processes becomes less concerned with issues of democratic legitimacy and more concerned with co-opting dissenting stakeholders and empowering those that will deliver neoliberal outputs (Raco, 2014). Post-political planning focuses on producing outputs which further neoliberal agendas (Wilson \& Swyngedouw, 2014). For example, during the Atlanta BeltLine project, planning agencies facilitated a growth-first approach by deploying a process that avoided adversarial politics, and defined what were appropriate planning outputs (e.g. gentrification opportunities (Roy, 2015). Post-political planning processes are validated through output-centred legitimisation (e.g. number of jobs created) rather than input-centred legitimisation (e.g. procedural justice). The legitimacy of post-political planning processes becomes secondary to the legitimacy of its outputs. Choreographed participation is deployed to disempower stakeholders and replace them with selected policy partners and technocratic experts who are best able to turn neoliberal objectives into outputs (Raco, 2014). 


\section{Technocratic-managerialism}

Technocratic-managerialism depoliticises decision making by replacing public debate with collaboration amongst technocrats and framing environmental problems as arising from data and knowledge gaps. Technocratic managerialism aggrandises experts and data in decision making so that they become the focus of policy interventions, often leaving pressing issues unaddressed (Swyngedouw, 2009, 2011a; Allmendinger \& Haughton, 2012). For example, marine user conflict and negative cumulative impacts arising from increased ocean industrialisation are not to be resolved through de-growth strategies but, rather, by enhanced data collection and expert analysis.

Technocratic-managerialism is positioned as capable of resolving, and therefore depoliticising, complex socio-environmental issues (Oosterlynck \& Swyngedouw, 2010). GIS and data portals are used to reduce complex marine socio-ecological relationships to apolitical spatial interactions (Smith \& Brennan, 2012) which, if conflictual, are fixable through the application of spatial planning expertise (Flannery et al., 2018). Although debate remains possible within these processes, it occurs within the limitations of elite consensus and the technocratic-managerial regime (Raco, 2014). The focus on technocratic-managerial solutions enables post-political planning to further ignore constructive debate and stakeholder knowledge (Dean, 2014), and to select policy actions from a narrow range of path-dependent options.

\section{Path dependency}

Path dependency acts as a modality of depoliticisation by limiting the scope of decisionmaking processes. Path dependency restricts actions to those that best fit with past decisions 
(Kirk, Reeves, \& Blackstock, 2007). Rather than decision making being a rational process of selecting optimal actions, it: a) occurs within bounded forms of rationality (i.e. a rationality that is limited by time, knowledge and cognitive boundaries); and b) focuses on selecting actions that are good enough to suit decision-makers' purposes (satisficing) but that are not necessarily optimal. For example, in the case of coastal management in Ireland, pathdependent policy layering within successive programmes designed to address fragmented management has failed to radically transform governance (Kelly, Ellis, \& Flannery, 2019).

Post-political planning is severely time-limited, which is usually self-imposed due it being legitimised through outputs (Raco, 2014), and the need to satisfy the momentum and speed requirements of capital (Harvey, 1985). By imposing time limitations, post-political planning facilitates path-dependent decision making by preventing alternatives from being considered (Kelly et al., 2019). This hasty decision-making limits decision-makers to choosing from a narrow range of actions (i.e. those palatable to the hegemonic regime).

The re-application of 'successful' practices from other spheres is also characteristic of path dependency. Post-political practices that enable the continuation of neoliberal capitalism within other arenas are viewed as successful. Adopting these practices because they 'worked' in another context reduces capacity to develop transformative practices attuned to local contexts. For example, English MSP is rationalised as a logical expansion of terrestrial planning practices (MMO, 2014b) despite these practices being critiqued as a mechanism for sustaining neoliberal growth (Allmendinger \& Haughton, 2012). Planning processes afflicted by the post-political condition tend to choose between a few, path-dependent actions rather than the wholescale reformation of ineffective governance regimes (Kelly et al., 2018). These 
path dependent actions are presented as novel solutions and give the appearance of progressive changes.

\section{Illusion of progressive change}

Post-political planning seems to facilitate progressive change. It appears to be concerned with producing stakeholder-informed, evidenced-based solutions, that conceals its conservative nature (Allmendinger \& Haughton, 2012). In the belief that they are working towards implementing progressive change, non-elite stakeholders can spend resources engaging with tokenistic processes and on the production of solutions that have been designed to not disrupt the hegemony. Illusions of progressive change are further amplified by empty signifiers, which are broad, meaningless terms under which a wide range of actions can be defended. Empty signifiers such as 'sustainable development' are common in environmental governance discourse and often represent hollow commitments or, more odiously, mask neoliberal agendas. Due to their ill-defined content, empty signifiers can frame problems and solutions in non-threatening ways, while hiding more malevolent agendas. For example, 'sustainable development' has become an empty signifier that hides the promotion of neoliberal governance behind hollow commitments to social and environmental issues (Swyngedouw, 2007). Although outwardly signifiers can stand for inclusivity, internally they facilitate repression of conflicting alternatives and are used to advance hegemonic power structures (Swyngedouw, 2007).

Post-political scholarship is not without criticisms. Dean (2014) argues that the post-political condition is the Left's response to the proficiency of right-wing hegemony-building practices. The construction of the post-political 'myth' is a consequence of the Left's inability to advance alternatives to neoliberalism (Dean, 2014). Rather than the post-political condition 
being an invention of the Left, there is clear evidence of it masquerading as progressive planning. For example, even its staunchest critics concede that the post-political lens helps to explain why "the near-universal acceptance of participatory planning" appears to make such little difference (Mitchell, Attoh, \& Staeheli, 2015, p. 2636). Beveridge and Koch (2017), argue that post-political theorists have over-simplified agency. They argue that the postpolitical condition suggests planning is dominated by an omnipresent and omnipotent ordering that, if true, would mean that change was impossible (Beveridge \& Koch, 2017). We argue that dominated or exploited stakeholders are producers of their situational context, with capacity to develop countermeasures to the post-political condition. For example, these stakeholders can and do become aware of the illusion of progressive change (Flannery et al., 2018) and seek out other avenues through which they can disrupt post-political planning processes. The issue then is not that these stakeholders are lacking in agency, it is that their agency in tackling one post-political symptom (e.g. choreographed participation) can be countered by other depoliticisation modalities (e.g. technocratic-managerialism). Rather than it being the Left's griping at the efficiency of neoliberalism, the post-political condition, therefore, provides a holistic lens through which to understand resistance to regime shifts and, through assessment of its interrelated symptoms, provides avenues through which to develop more transformative strategies.

\section{Study site and methodology}

England was selected for our study site as it was one of the first countries to develop statutory MSP. In 2014, the Marine Management Organisation (MMO) published plans for the East Inshore and Offshore areas. The East Inshore area includes coastline from Flamborough Head to Felixstowe and extends from the mean high-water mark to 12 nautical miles (Fig 1). The East Offshore area covers the marine area from 12 nautical miles out to the limit of the UK 
Exclusive Economic Zone (Fig 1). The resulting plans are collectively referred to as the East Marine Plans (EMPs).

\section{[insert fig 1 near here]}

Our study consists of semi-structured interviews and document analysis. During 2016, interviews were conducted with 19 stakeholders from: NGOs; politics; public sector; energy; and fishing. Semi-interviews focused on: perception of English marine governance systems; participation in and perception of the planning process; perception of the resulting plans; and future MSP challenges. All interviewees had participated in developing the EMPs. Interviews lasted approximately 60 minutes and were recorded and transcribed. Documents analysed include: Marine and Coastal Access Act 2009; UK Marine Policy Statement (HM Government, 2011); A Description of the Marine Planning system in England (DEFRA, 2011); Statement of Public Participation (MMO, 2013); East Inshore and Offshore Marine Plans (DEFRA, 2014); Analysis of the East Inshore and Offshore Marine Plans (MMO, 2014a); and Sustainability Appraisal (MMO, 2014b). Interview transcripts and documents were thematically analysed using the post-political symptoms as deductive themes.

\section{Findings}

Findings from the analyses are presented below as they relate to the symptoms of the postpolitical condition. Findings that did not correspond to the analytical framework included affirmative comments by Public Bodies that framed English MSP as being better than the previous regime. 


\subsection{Neoliberalism}

Typical of neoliberal projects, the Statement of Public Participation (MMO, 2013)

emphasises how the economic benefits fostered by the EMPs will act as solutions to a range of problems, including, poverty alleviation:

East Inshore and East Offshore plan areas were selected as the first plan areas in England for a number of reasons which include: its wide range of marine activities, potential for future sustainable development and its contribution to the national economy; its range of communities, including less well off areas that will benefit from economic confidence in sustainable development (MMO, 2013, p. 5).

Analysis of the plans, however, indicates that they contain no actions to deliver direct benefits to less well-off communities and their realisation appears to rely on trickle-down 'Blue

Growth'. EMPs contain no strategy for distributing these benefits, with the implication being that this will be facilitated by the market. This trickle-down economic logic was questioned by interviewees:

That wind farm may be big, expensive and make lots of money, but it doesn't make it in or for this area [...] It provides a lot of jobs, but where are those jobs going? Well, there are service boats running technicians out and it's not a local company. The engineers and technicians have been brought in from other projects, the project managers are from elsewhere. It's not creating any jobs locally; it's not putting any money into the local economy (Fisheries 3).

This critique of Blue Growth is similar to criticisms emerging in the literature, which suggests that the benefits of growth sectors may not be realised in coastal areas. There is a tendency for high-value-added activities associated with Blue Growth to remain in urban hubs, with minimal increases in coastal community labour forces (Morrissey, 2017).

Economic benefits of MSP are also framed in neoliberal terms. MSP is advanced as providing certainty to investors, and for removing the bureaucratic burden on industry.

Within the EMPs, planning is no longer focused on acting in the public interest, but, instead, 
is concerned with facilitating greater resource exploitation in the most efficient (i.e.

neoliberal) manner:

[The EMPs] will provide greater certainty for developers based around compatibility with the agreed area objectives (DEFRA, 2011, p. 11).

[The EMPs] will help to reduce the overall regulatory burden on applicants and users, by acting as an enabling mechanism for those seeking to undertake activities or development in the future, and providing more certainty about where activities could best take place (DEFRA, 2014, p.8).

The scope of MSP was restricted so that it would not burden industry, resulting in the EMPs containing mainly strategic-level objectives. The need to find lowest common denominator solutions acceptable to a broad range of stakeholders is blamed for MSP developing strategic rather than operational objectives (Flannery \& Ó Cinnéide, 2012c). In our study, however, a public body interviewee indicated that the intention was to develop more detailed objectives but that this was rejected by the Government, who wished to minimise 'negative' impacts on industry:

We tried to make policies more detailed and specific however because it was new and the government didn't want to add burden, some of those policies didn't go forward and it resulted in the polices that we have got now (Public Body 1).

Key documents emphasise the economic benefits that will accrue from MSP and illustrate its neoliberal predisposition. The high-level objectives of the Marine Policy Statement (UK Parliament, 2011) frames MSP in soft sustainability terms, wherein the need for marine industries to act sustainably is couched in terms of economic benefits:

Marine businesses are acting in a way which respects environmental limits and is socially responsible. This is rewarded in the marketplace. (HM Government, 2011). 
Neoliberalism is not just concerned with providing certainty to industry, it must also act as an accelerator for capital (Harvey, 2017). This trait is evident in the EMPs which are constructed as a mechanism for reducing the time it takes from an industry proposing a development to it being licensed:

[The EMPS] should provide developers with greater certainty on where to invest their capital, ensuring that marine projects benefit from the right information at the right time, so they can move as quickly as possible from 'concept to consent' (DEFRA, 2014, p. 8).

Marine users [...] should find that the system will reduce the regulatory burden on them by giving them more certainty regarding where activities could best take place and thereby speed up the licensing process (MMO, 2013, p. 3).

\subsection{Choreographed participation}

The EMPs' documents contain numerous statements about inclusive engagement, wide participation and collaborative planning. However, for interviewees, engagement was viewed as being tokenistic, appearing to do little more than repeat exercises that had been conducted for other purposes:

I was at a few of the early kick-off meetings [...] it was very much, we're going to work out who can do what and how their activities overlap. It gradually become a case of, well we're actually going to signpost everything and we're not going to come up with anything new [...] It was very odd when it came out, seeing the same kind of questions being asked [as were asked in the consultation process for marine conservation zones] in a slightly different context (Developer 6).

The planning process was criticised by interviewees for not facilitating meaningful engagement and for failing to alter the status quo. Some interviewees fell into the 'illusion of inclusion' trap and were happy to be involved in meaningless dialogues while lamenting their failure to make a difference:

I don't think [the marine plans] made a great deal of difference [...] the results the same, the developments are invariably passed, but what is does is open a dialogue (Fisheries 3). 
The participatory processes were perceived by interviewees as being choreographed. In their opinion, the process was meaningless, in the sense that it enabled participants to voice their opinions but not have an impact. They described the planning process as inconsequential, as it focused on mapping and signposting existing policies:

I used to think MSP was a good idea and then in practice, as it has developed it just seems to be a giant signposting exercise to tell you what's already there rather than a plan (Developer 6).

\subsection{Technocratic-managerialism}

The planning process was less concerned with meaningful engagement, with its real focus being on collating and mapping existing activities, policies and objectives. This had the effect of transforming participation into a technocratic-managerial process. Rather than focus on forward planning, the process became about gathering evidence to support a narrow range of objectives. The technocratic-managerial focus on gathering spatial data was used to create an illusion of inclusion, sometimes recollecting data that had been collected for other processes. To legitimise the status quo, post-political practices adopt the logic of participatory processes whilst utilising decision-making practices that do not challenge existing power relations. With the pretence of democratic legitimacy, post-political practices create the illusion of participation by employing an undemocratic process (Roy, 2015; Flannery et al. 2018). Interviewees recognised the need to gather data relating to the marine area, however, processes used were repetitive and did not transform marine management:

[The MMO] came around with all these roadshows and basically saying, were going to get this data together and do these great things, when surely that's already been done as part of the MCZ process. You were mapping pressures, activities and habitats, so it just seemed like here we go again (Developer 6). 
Interviewees stated that the emphasis on mapping what was there, rather than planning for future use, was a key shortcoming of the EMPs. MSP was perceived as missing its point as it did not go beyond mapping and data gathering:

It's moving beyond the maps and asking how do we work, how does the MMO in most cases but not all, actually manage stuff and take into account those competing requirements and I think that's the bit we haven't really seen. It's the management element rather than this kind of telling us there's a plan for everything (Developer 6).

The evidence base of the plan is used to provide certainty for industry investment and to eliminate debate and discussion about futures scenarios. Opportunities to contest policies or subsequent decisions were all but removed. The focus on data production within the plans means that opportunities to contest the prioritisation of particular sectors were foreclosed, as decisions could be defended as being based on best available scientific evidence. Developer compliance with the plans is, therefore, framed as making future development incontestable:

Marine users should also feel more confident that decisions made on applications for projects will be robust in the face of challenge, provided they are made in accordance with marine plans. This is because plans will be based on the best available technical and scientific evidence (MMO, 2013, p. 3).

Despite the emphasis on having a strong evidence base and the focus on data gathering, EMPs' documents highlight several known data gaps (e.g. ecological, economic; fishing landscape and seascape):

Gaps in the evidence base along with recent revisions to national planning policy have resulted in these first marine plans not including specific spatial or resource allocations for some policies (MMO, 2014b, p. 8).

Yet, due to bounded rationality, there were superficial attempts to address these gaps.

Addressing these gaps would have taken time and resources, slowing down the momentum of 
capital. The planning process, therefore, gave the appearance of momentum and change while not doing anything new.

\subsection{Path dependency}

MSP adopted the English terrestrial planning framework as this constitutes a "best practice approach" (MMO, 2014b, p. 32). The English terrestrial planning approach is portrayed within these documents as successful and, therefore, its re-application is deemed to be a logical approach. Ignoring well-established issues with the terrestrial planning framework, its re-application for MSP is a path-dependent decision which undermines the capacity to be adaptive to the uniqueness of marine issues.

The EMPs do not adopt a forward-looking approach but instead are concerned with restating previous policy decisions. Activities previously licenced or deemed strategically important to the economy were prioritised within the plans, disregarding the need to consider alternative uses and trade-offs. MSP was, therefore, perceived by interviewees as a process of mapping previous decisions, rather than planning:

The process that they went through to develop [these plans] was intrinsically linked to licencing, especially with the wind sector because it wasn't like they were starting from a blank canvas and saying where the best place to put offshore wind zones is. Those zones had already been decided (Public Body 3).

Even during the sustainability appraisal process, the alternative planning options that were explored were very limited, focusing on sectoral prioritisation of wind, co-location of wind and other activities, and varying degrees of support for aggregates. Spatially prescriptive plans were ruled out by the planning team due to this not being desired by stakeholders and a lack of evidence for a prescriptive zoned approach. The focus was placed on developing policies related to sectoral prioritisation, as this was deemed to be the main area where the 
plan could add value (MMO, 2014b). By prioritising prominent economic sectors, the EMPs became about collating sectoral priorities, rather than holistic, forward-looking planning:

It inherited the fact that the round three leasing had already happened and that these areas had already been identified as important and able to be developed through a totally separate process and they were in the early stages of zonal development (Developer 5).

The EMPs, therefore, exhibit a preference for preserving the status quo over developing progressive objectives. This propensity is apparent in oil and gas policies in the plans, which, despite the UK Marine Policy Statement (HM Government, 2011) containing a commitment to use MSP to transition to a low-carbon economy, state that oil and gas projects are to be supported in areas previously licenced for extraction over other developments within the same area:

Proposals for new oil and gas activity should be supported over proposals for other development (DEFRA, 2014, p. 115).

\subsection{Illusion of progressive change}

Doing little more than collate existing policies illustrates the failure of the EMPs to bring about progressive change. Interviewees were dissatisfied with the vagueness and non-specific nature of the plans. For interviewees the plans are inconsequential in terms of shaping future action, and were frustrated that the plans do not add specificity to exiting policies and objectives:

We didn't have anything before we had the marine plans and we don't have anything now that we've got the marine plans, they are pieces of paper (Fisheries 3).

Even offshore wind farm developers, who would appear to benefit most from the EMPs' economic focus, question whether the plan instigated any changes, indicating that they can ignore them when developing projects: 
Yes, we refer to it, but it's almost an exercise of how can we get this in and what can we really say. So there are a few paragraphs and then we never refer to it again. There are stronger drivers that need to be referred to (Developer 6).

\begin{abstract}
I think certainly that the general perception or assumption will be that if you have regard to the Marine Policy Statement, which the marine plans were supposed to interpret, that actually meets the requirements of the marine plan. (Developer 2).
\end{abstract}

\title{
5. Discussion and development of disruptive alternatives
}

Our analysis illustrates how English MSP suffers from the post-political condition and the interconnected nature of its symptoms. Similar to other post-political planning processes, 'problems' are to be addressed through neoliberal solutions including, inter alia, trickle-down economics, reduced bureaucratic burden and facilitating capital's momentum. The focus on implementing neoliberal planning solutions resulted in the plans being developed in a pathdependent manner. This bounded rationality framed problems through a neoliberal lens and no new knowledge was needed, even when knowledge and data gaps were identified, as industry goals and objectives had been formulated within previous policy processes. The aim of the EMPs could not be viewed as the simple adoption of sectoral policy and objectives, and, therefore, these policies had to be cleansed of their obvious neoliberal bias by passing through elaborate, but ultimately pointless, participatory and technocratic-managerial processes. This should not be construed as the planning process requiring input forms of legitimisation. Rather, participatory processes were employed to provide an impression of democratic legitimacy and technocratic-managerialism administered the benediction of 'science' to provide an illusion of best practice and progressive change.

Although the symptoms of the post-political condition are interrelated and difficult to address individually, we do not see the post-political condition as omnipotent or inescapable 
(Beveridge \& Koch, 2017) nor the public as incapable of (re)shaping planning processes. Despite striving to deprive society of its political nature, the post-political condition does not fully foreclose the political (Metzger, 2017). In other words, society remains capable of revolution (Mouffe, 2005). The power of the post-political condition emanates from the interrelated nature of its symptoms. We argue that there is a need to address these symptoms collectively if we are to understand the depoliticisation of MSP and to resist its further decline into the post-political trap.

We offer suggestions for the re-politicisation of MSP as alternatives to the post-political practices identified in our study. We do not naively believe that MSP will be in the vanguard of the assault on broader neoliberal regimes. Rather, we suggest modalities of repoliticisation that can address the all-encompassing nature of post-political MSP. We believe that post-political MSP is best addressed by addressing three core issues simultaneously: recentralizing conflict in marine governance; the deliberate redesign and transformation of marine governance regimes; and the development of strategies to empower stakeholders.

The focus on reducing conflict in marine governance removes debate about the purpose of MSP. The potential of MSP resides in its capacity to imagine alternative futures. As in our case study, this potential has been lost, as MSP has narrowly focused on the rational use of marine space and reducing spatial conflicts. MSP, however, should be a political process of exploring and debating future visions for the ocean, with the overall view of instigating radical change and redirecting us from our unstainable pathways. Rather than acting as a mechanism for the further neoliberalisation of marine governance, MSP should provide space for public debate about alternative futures. Limiting the goal of MSP to a narrow economic remit excludes important debates from MSP (e.g. poverty alleviation; climate change etc.). 
Instead of removing these conflicting narratives, MSP should recognise the value of agonism (Tafon et al., 2018). Rather than take the form of antagonistic conflict (i.e. struggle between enemies), debates should take the form of democratically productive agonism (i.e. a dynamic process of continual debate between adversaries) (Mouffe, 1999; Metzger, 2017). Differences between actors must be brought into a public forum in which they can be explored and articulated (Metzger, 2017). In the case of proposed offshore wind development in Estonia, MSP practices did not provide sufficient space for debate (Tafon et al., 2018). Subsequently, Tafon et al. (2018) suggest the use of 'pragmatic adversarialism', whereby planners develop governance norms to tackle issues such as the inequity caused by privatising space. In doing so, it is suggested that space will be provided for stakeholders to vocalise their values and ideals while acknowledging the right of rivals to articulate and promote their views with equal passion.

Facilitating debate within the narrow remit of existing governance structures would be pointless, and there must be scope within MSP discussions about the structural changes needed to achieve more holistic objectives. A more radical form of MSP would, therefore, facilitate discussion about necessary governance regime changes. Long-term vision exercises for developing different marine futures should be supported by a reflective process for exploring and implementing the governance changes need to give practical effect to these visons. This could be facilitated by adopting a transition management approach to designing and implementing the holistic governance regime promises, but not delivered, by MSP (Kelly et al., 2018). The transition management approach is recognised as a way of overcoming path dependency and highlighting the intransient nature of powerful actors (Kelly et al., 2019). In the Netherlands, deliberation around the transformation of energy systems was managed using transition management (Loorbach, 2010). By exploring multiple different trajectories, 
transition management provided a reflexive governance model that broke with the consensual tradition of policymaking, and so overcame symptoms associated with the post-political condition, such as choreographed participation Loorbach, 2010). Alternatively, existing MSP processes could be reformatted so that they are more reflexive and open to changing contemporary governance practices. To overcome institutional inertia, MSP processes should facilitate actors to reflect on the rules of the game and if they need to be changed, and challenge existing discourses (van Tatenhove, 2017).

Finally, a more radical form of MSP should focus on empowering stakeholders. It can do this in two ways: empowering stakeholders to produce and use alternative knowledge; and foster greater stakeholder capacity to engage with planning processes. Meaningful participation rather than one-way consultation processes, encouraged collaboration, ownership, and is critical to the success of environmental programmes (Bennett \& Dearden, 2014). By producing and making use of alternative knowledges, stakeholders can begin to counter the prevailing narratives and rationalities within marine governance. Their capacity to produce such knowledge could be enhanced through citizen science (Nursey-Bray, Palmer, \& Pecl, 2018; Kelly, Flemming, Pecl, Ritcher, \& Bonn. 2019) and participatory mapping (Boucquey, St Martin, Fairbanks, Campbell, \& Wise, 2019) projects that would enable them to provide alternative data to the technocratic, top-down forms of data collection. Attention to inclusive decision-making processes that confront issues of social justice is essential to achieving sustainable ocean management across sectors and jurisdictions (Bennett, 2018). In the case of fisheries management, participatory mapping rendered fishing communities visible, providing an opportunity for better area-based management that provided opportunities for community development (St Martin \& Hall-Aber, 2008). Stakeholder capacity to engage with planning processes can be enhanced through the use of skilled intermediaries, including environmental 
non-government organisations (Brooker, Hopkins, Devenport, Greenhill, \& Duncan, 2019) and advocate planners (Flannery et al., 2016; Tafon et al., 2018; Saunders, Gilek, \& Tafon, 2019). These intermediaries can have either social or environmental remits and have the knowledge, lobbying, political and planning skills to act in the interest of the public and marginalised stakeholders. For example, as advocates, planners can raise awareness of the uneven power relations and inequitable effects of post-political planning, and by doing so, advocate for initiatives that seek more democratic and just change (Saunders et al., 2019).

We do not seek to resist the idea of MSP, but, rather, argue that its radical potential needs to be reclaimed through modalities of re-politicisation, such as we have outlined above. The global uptake of MSP demands that attention is paid to understanding how a regressive form of MSP has emerged in practice and necessitates the recalibration of MSP so that its transformative capacity may be realised. While MSP's staunchest advocates evoke Victor Hugo's maxim that 'one cannot resist an idea whose time has come' to describe the rapid ascendency of MSP, they must acknowledge the growing evidence of a gap between the ideas of MSP and how it has been implemented. As MSP will continue to expand, especially due to it being championed by supranational organisations, future research must evaluate if it reforms marine governance and, where it does not, must explore radical alternatives.

\section{References}

Allmendinger, P., \& Haughton, G. (2012). Post-political spatial planning in England: a crisis of consensus? Transactions of the Institute of British Geographers, 37(1), 89-103.

Bennett, N. J., \& Dearden, P. (2014). From measuring outcomes to providing inputs: Governance, management, and local development for more effective marine protected areas. Marine Policy, 50, 96-110.

Bennett, N. J. (2018). Navigating a just and inclusive path towards sustainable 
oceans. Marine Policy, 97, 139-146.

Beveridge, R. and Koch, P., 2017. The post-political trap? Reflections on politics, agency and the city. Urban Studies, 54(1), pp.31-43.

Boucquey, N., St Martin, K., Fairbanks, L., Campbell, L. M., \& Wise, S. (2019). Ocean data portals: Performing a new infrastructure for ocean governance. Environment and Planning D: Society and Space, 0263775818822829.

Brooker, E. E., Hopkins, C. R., Devenport, E., Greenhill, L., \& Duncan, C. (2019). Civil society participation in the Scottish marine planning process and the role of Environmental Non-Governmental Organisations. Journal of Environmental Planning and Management, 1-23.

Blühdorn, I. (2014). Post-ecologist governmentality: Post-democracy, post-politics and the politics of unsustainability. In: Wilson. J., \& Swyngedouw, E., (Eds) The post-political and its discontents: Spaces of depoliticisation, spectres of radical politics. P. 146-166. Edinburgh. Edinburgh University Press,

Dean, J. (2014). After Post-Politics: Occupation and the Return of Communism. In: Wilson. J., \& Swyngedouw, E., (Eds) The post-political and its discontents: Spaces of depoliticisation, spectres of radical politics. P. 261-278. Edinburgh. Edinburgh University Press.

DEFRA. (2011). A description of the marine planning system for England. DEFRA. London. DEFRA. (2014). East Inshore and East Offshore Marine Plans. London.

Ehler, C. N. (2018). Marine spatial planning: An idea whose time has come. In Yates, K. L., Bradshaw, C. J. A., (Eds). Offshore Energy and Marine Spatial Planning (p. 6-17). Routledge.

Flannery, W., \& Cinnéide, M. Ó. (2012a). A roadmap for marine spatial planning: A critical examination of the European Commission's guiding principles based on their application in the Clyde MSP Pilot Project. Marine Policy, 36(1), 265-271.

Flannery, W., \& Ó Cinnéide, M. (2012b). Deriving lessons relating to marine spatial planning from Canada's eastern Scotian shelf integrated management initiative. Journal of Environmental Policy \& Planning, 14(1), 97-117.

Flannery, W., \& Ó Cinnéide, M. (2012c). Stakeholder participation in marine spatial planning: Lessons from the Channel Islands National Marine Sanctuary. Society \& Natural Resources, 25(8), 727-742.

Flannery, W., Ellis, G., Nursey-Bray, M., van Tatenhove, J. P., ... \& Jentoft, S. (2016). Exploring the winners and losers of marine environmental governance/Marine spatial 
planning: Cui bono?/"More than fishy business": epistemology, integration and conflict in marine spatial planning/Marine spatial planning: power and scaping/Surely not all planning is evil?/Marine spatial planning: a Canadian perspective/Maritime spatial planning_"ad utilitatem omnium"/Marine spatial planning:"it is better to be on the train than being hit by it"/Reflections from the perspective of recreational anglers ....

Planning Theory \& Practice, 17(1), 121-151.

Flannery, W., Healy, N., \& Luna, M. (2018). Exclusion and non-participation in Marine Spatial Planning. Marine Policy, 88, 32-40.

Flannery, W., Clarke, J., \& McAteer, B. (2019). Politics and Power in Marine Spatial Planning. In Zaucha, J., \& Gee. K. (Eds.) Maritime Spatial Planning (pp. 201-217). Palgrave Macmillan, London

Harvey, D. (1985). The Urbanization of Capital Johns Hopkins University Press. Baltimore, MD.

Harvey, D. (2007). Neoliberalism as creative destruction. The annals of the American academy of political and social science, 610(1), 21-44.

Harvey, D. (2017). Marx, capital, and the madness of economic reason. Oxford University Press.

HM Government. (2011). The UK Marine Policy Statement. London. HMSO, The Stationery Office

Haughton, G., Allmendinger, P., \& Oosterlynck, S. (2013). Spaces of neoliberal experimentation: soft spaces, postpolitics, and neoliberal governmentality. Environment and Planning A, 45(1), 217-234.

Jones, P. J., Lieberknecht, L. M., \& Qiu, W. (2016). Marine spatial planning in reality: Introduction to case studies and discussion of findings. Marine Policy, 71, 256-264.

Kelly, C., Ellis, G., \& Flannery, W. (2018). Conceptualising change in marine governance: Learning from Transition Management. Marine Policy, 95, 24-35.

Kelly, C., Ellis, G., \& Flannery, W. (2019). Unravelling persistent problems to transformative marine governance. Frontiers in Marine Science, 6, 213.

Kelly, R., Fleming, A., Pecl, G., Richter, A., \& Bonn, A. (2019). Social license through citizen science: a tool for marine conservation. Ecology and Society, 24(1)

Kirk, E. A., Reeves, A. D., \& Blackstock, K. L. (2007). Path dependency and the implementation of environmental regulation. Environment and Planning C: Government and Policy, 25(2), 250-268.

Loorbach, D. (2010). Transition management for sustainable development: a prescriptive, 
complexity-based governance framework. Governance, 23(1), 161-183.

Metzger, J. (2017). Postpolitics and planning. The Routledge handbook of planning theory, 180-193.

MMO. (2013). East Inshore and East Offshore marine plan areas Statement of Public Participation : Revised August 2013. Newcastle upon Tyne.

MMO. (2014a). Analysis of the East Inshore and East Offshore Marine Plans. Newcastle upon Tyne.

MMO (2014b). Sustainability Appraisal of the East Inshore and East Offshore Marine Plans, Volume 2: Sustainability Appraisal. Newcastle upon Tyne.

Morrissey, K. (2017). It's not just a Blue Economy moment.... Dialogues in Human Geography, 7(1), 42-44.

Mitchell, D., Attoh, K., \& Staeheli, L. (2015). Whose city? What politics? Contentious and non-contentious spaces on Colorado's Front Range. Urban Studies, 52(14), 2633-2648.

Mouffe, C. (1999). Deliberative democracy or agonistic pluralism?. Social research, 745758.

Mouffe, C. (2005). The return of the political (Vol. 8). Verso. London.

Nursey-Bray, M., Palmer, R., \& Pecl, G. (2018). Spot, log, map: Assessing a marine virtual citizen science program against Reed's best practice for stakeholder participation in environmental management. Ocean and Coastal Management, 151, 1-9.

Oosterlynck, S., \& Swyngedouw, E. (2010). Noise reduction: the postpolitical quandary of night flights at Brussels airport. Environment and Planning A, 42(7), 1577-1594.

Raco, M. (2014). The post-politics of sustainability planning: privatisation and the demise of democratic government. In: Wilson. J., \& Swyngedouw, E., (Eds) The post-political and its discontents: Spaces of depoliticisation, spectres of radical politics. (p. 25-47. Edinburgh. Edinburgh University Press,

Ritchie, H., \& Ellis, G. (2010). 'A system that works for the sea'? Exploring stakeholder engagement in marine spatial planning. Journal of environmental planning and management, 53(6), 701-723.

Roy, P. (2015). Collaborative planning-A neoliberal strategy? A study of the Atlanta BeltLine. Cities, 43, 59-68.

Sander, G. (2018). Ecosystem-based management in Canada and Norway: The importance of political leadership and effective decision-making for implementation. Ocean \& coastal management, 163, 485-497. 
Saunders, F. P., Gilek, M., \& Tafon, R. (2019). Adding People to the Sea: Conceptualizing Social Sustainability in Maritime Spatial Planning. In Zaucha, J., \& Gee. K. (Eds.) Maritime Spatial Planning (p. 175-200). Palgrave Macmillan, London

Smith, G., \& Brennan, R. E. (2012). Losing our way with mapping: thinking critically about marine spatial planning in Scotland. Ocean \& coastal management, 69, 210-216.

Smith, G., \& Jentoft, S. (2017). Marine spatial planning in Scotland. Levelling the playing field?. Marine Policy, 84, 33-41.

Smith, G. (2018). Good governance and the role of the public in Scotland's marine spatial planning system. Marine Policy, 94, 1-9.

St. Martin, K., \& Hall-Arber, M. (2008). Creating a place for" Community" in New England fisheries. Human Ecology Review, 161-170.

Swyngedouw, E. (2007). Impossible sustainability and the post-political condition. In Making strategies in spatial planning(pp. 185-205). Springer, Dordrecht.

Swyngedouw, E. (2009). The antinomies of the postpolitical city: in search of a democratic politics of environmental production. International Journal of Urban and Regional Research, 33(3), 601-620.

Swyngedouw, E. (2011a). Interrogating post-democratization: Reclaiming egalitarian political spaces. Political geography, 30(7), 370-380.

Tafon, R. V. (2017). Taking power to sea: Towards a post-structuralist discourse theoretical critique of marine spatial planning. Environment and Planning C: Politics and Space, 36(2), 258-273.

Tafon, R., Howarth, D., \& Griggs, S. (2018). The politics of Estonia's offshore wind energy programme: Discourse, power and marine spatial planning. Environment and Planning C: Politics and Space, 2399654418778037.

van Tatenhove, J.P. (2013). How to turn the tide: developing legitimate marine governance arrangements at the level of the regional seas. Ocean \& Coastal Management, 71, pp.296-304.

van Tatenhove, J. P. (2017). Transboundary marine spatial planning: a reflexive marine governance experiment?. Journal of Environmental Policy \& Planning, 19(6), 783-794.

Wilson, J., \& Swyngedouw, E. (2014). Seeds of dystopia: Post-politics and the return of the political. In: Wilson. J., \& Swyngedouw, E., (Eds) The post-political and its discontents: Spaces of depoliticisation, spectres of radical politics, (p.1-22). Edinburgh. Edinburgh University Press, 


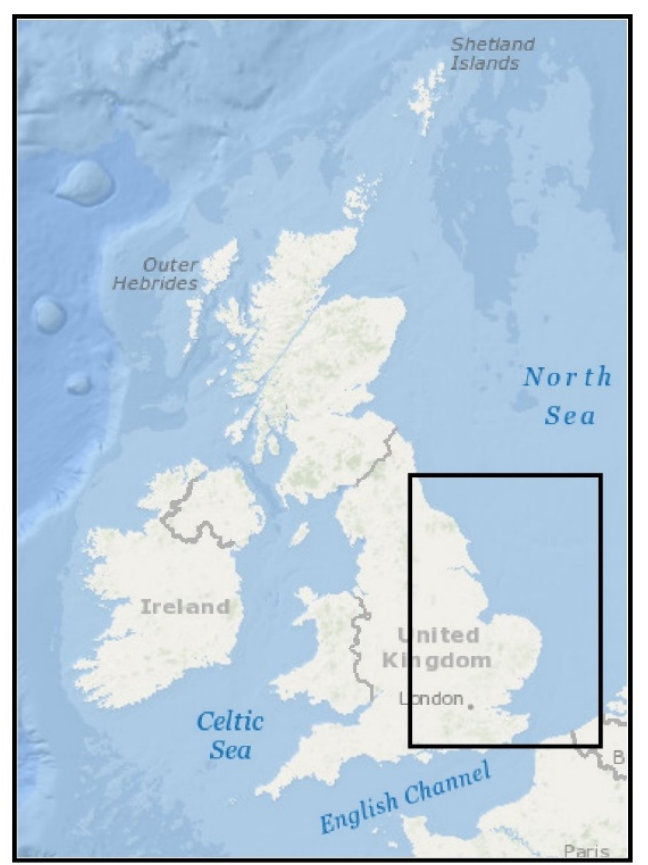

Q7 East Inshore Marine Plan area

$\cdots$ East Offshore Marine Plan area

Service layer World Ocean Base, World Ocean Reference source ESRI. Marine Management Organisation Marine

Plan Areas; source Marine Managemnet Organisation with

Open Government licence.

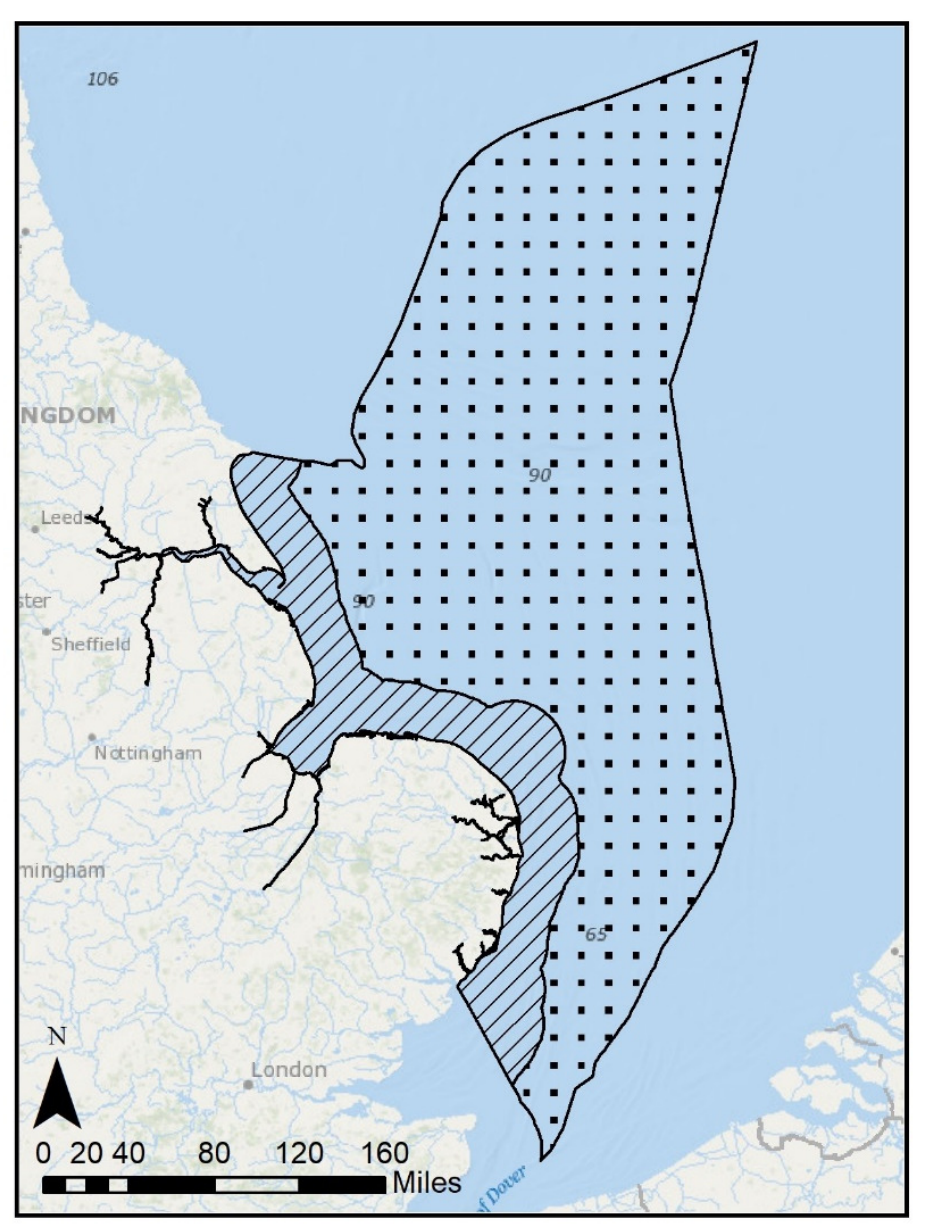

Fig 1. Study site 